\author{
Faculty Research Working Papers Series
}

\title{
Dynamics and Regulation of the Asian Pharmaceutical Industry: A Critical Review
}

\author{
F. M. Scherer \\ John F. Kennedy School of Government - Harvard University
}

April 2008

RWP08-021

The views expressed in the HKS Faculty Research Working Paper Series are those of the author(s) and do not necessarily reflect those of the John F. Kennedy School of Government or of Harvard University. Faculty Research Working Papers have not undergone formal review and approval. Such papers are included in this series to elicit feedback and to encourage debate on important public policy challenges. Copyright belongs to the author(s). Papers may be downloaded for personal use only. 


\title{
DYNAMICS AND REGULATION OF THE ASIAN PHARMACEUTICAL INDUSTRY: A CRITICAL REVIEW
}

\author{
F. M. Scherer \\ Harvard University \\ March 2008 Revision
}

\begin{abstract}
The papers assembled for this conference provide broad and deep insights into the pharmaceutical industries of Asia. By my calculations, the nations on which the conference focused were home to some 2.6 billion individual human beings in the year 2000 , or 42.8 percent of the world's population. Among the nations analyzed are several highly-developed entities and some (comprising the bulk of the population covered) still marked by low average incomes per capita. In several of the less wealthy nations, recent economic growth has been rapid, so the provision of health care, including modern pharmaceuticals, to their citizens poses especially immediate challenges.
\end{abstract}

Desiring a broad overview on the condition of Asia's pharmaceutical industries, I sought statistics on pharmaceutical sales and domestic pharmaceutical production volumes in the individual nations. My search yielded only partial success. In its report on The World Medicines Situation: 2004, the World Health Organization estimated the dollar value (at prevailing exchange rates) of pharmaceutical production in a substantial sample of nations. ${ }^{1}$ I underline in, since, presumably, the difficult task of disentangling the production of multinationals outside their home bases and assigning it to the host country was attempted -- how successfully, one does not know. Table 1 reproduces the values for 1997, the last year covered, for the top 20 nations and for other Asian nations on which data were available. For many nations there are data gaps -- e.g., for Russia, Ireland, Israel, Poland, the Czech Republic, and Hungary among possibly substantial producers and for Taiwan and Vietnam among Asian nations. And there is reason to believe that some nations' industries have expanded significantly during the past ten year, rendering the figures somewhat out-of-date.

1 . An older source is R. J. Ballance, J. Pogany, and H. Forstner, The World's Pharmaceutical Industries: An International Perspective on Innovation, Competition and Policy (Edward Elgar: 1992). 
Recognizing that many Asian nations have experienced rapid economic development through export-oriented strategies, I also obtained evidence on the relative success of Asian countries in exporting to the world's most lucrative market for pharmaceuticals: the United States. My curiosity on this point was heightened by recent reports in diverse newspapers, one of them quoted in the paper by Santoro and Liu, that the United States imports some 80 percent of the pharmaceuticals or "pharmaceutical ingredients" (whatever that means) consumed domestically. ${ }^{2}$

The results of my investigation are summarized in Figure $1 .^{3}$ Total U.S. pharmaceutical imports were on the order of $\$ 82$ billion in 2006. By any measure, this falls far short of the 80 percent figure reported in the press. According to the Annual Survey of Manufactures for 2006, the value of pharmaceutical, medicinal, and biological product shipments from U.S. establishments in the same year was $\$ 158$ billion. Exports from U.S. producers were roughly $\$ 31$ billion. Thus, the total U.S. market for pharmaceuticals must have approximated the value of imports (82 billion) plus domestic plant shipments ( $\$ 158$ billion) minus the value of exports ( $\$ 31$ billion), or $\$ 209$ billion. Admitting that a considerable but unknown amount of double counting may reside in that total, ${ }^{4}$ imports are found to be roughly 39 percent of the total, not 80 percent.

More importantly for our immediate concern, only two Asian Pacific nations -- Singapore and Japan -- are found among the top 12 pharmaceutical importers to the United States. Singapore, ranked seventh in Figure 1, like

2 . The report apparently came from Congressional testimony by witnesses from the Government Accountability Office. I was unable to find any document among GAO reports posted electronically. Santoro's citation came from the Wall Street Journal, February 14, 2008; mine from the Boston Globe, February 3, 2008; and the New York Times, November 2, 2007. An earlier GAO report on "Prescription Drugs," GAO-05-372, September 2005, dealt only with drugs imported by mail, whose volume was believed to be "substantial and rising," although reliable data were unavailable.

3 . The data are from U.S. Census Bureau, "U.S. Imports from All Countries from 2002 to 2006 by 5-Digit End-Use Code," and "Shipments from Puerto Rico to the United States by Schedule B Commodity and Method of Transportation: Census Year 2006," both found on the Census Bureau web site.

4 . E.g., as active ingredients are produced at one or more sources and encapsulated in other factories. 
Puerto Rico and Ireland, draws pharmaceutical manufacturing in part because of its unusually low corporate income tax rates. ${ }^{5}$ It has also made a major effort to attract science-based biotechnology enterprises. Among Asian Pacific nations not included in Figure 1, India placed 16th shipping to the U.S. imports of $\$ 799$ million, China 17th with $\$ 676$ million, Australia 21st with $\$ 305$ million, South Korea 23rd with $\$ 63$ million, and Taiwan 24th with \$36 million. Imports from other Asian nations -- notably, Thailand, the Philippines, HongKong, Indonesia, Malaysia, and New Zealand -- totalled \$41 million.

\section{India}

Most surprising to me was the relatively weak performance of India suggested by the Figure 1 data. After Italy ended its policy of denying patent protection for pharmaceutical products in 1978, India moved forward to become the world's leading exporter of generic drugs, seizing a first-mover advantage by supplying drugs in patent-free markets (including its home market) long before product patents expired in the principal industrialized nations. Indian pharmaceutical firms, with estimated global sales of \$32 billion in 2007, have been particularly aggressive in supplying anti-retrovirals at steeply discounted prices to AIDS care-providers in low- and middle-income nations, accounting for 69 percent of the total ARV supply (by quantity) to such nations between 2005 and 2006. ${ }^{6}$ Cipla, the leader in the low-price ARV effort, originated 51 percent of the total Indian supply. Altogether, India is said to have 75 plants approved by the U.S. Food and Drug Administration for supply to the American market -- the most of any nation other than the United States itself. ${ }^{7}$ The forte of Indian companies during the 1990s and early 2000s

5 . Puerto Rico was apparently treated as part of the Continental United States in the Table 1 compilation. The Puerto Rican tax advantage under Section 936 of the U.S. tax code, implemented in 1976, was phased out as of December 31, 2005. However, established plants continued to produce because of sunk costs, accumulated skills, and the continuation of provisions allowing duty-free importation into the United States. In addition to having the lowest corporate income tax rates of Western European nations, Ireland provided university-level education in science and engineering to an unusually large fraction of its youth.

6 . Cipla News Release dated June 12, 2007, at http://www. ciplla.com/whatsnew/news.htm.

7 . "India Poised for Pharmaceutical Boom," Christian Science Monitor, January 2, 2007, found at http://www.csmonitor.com/ 2007/0102/p06s01-wosc.html. 
was low-price generic drugs. For example, in February 2008 U.S. pharmacies began selling cetirizine hydrochloride (brand name Zyrtec), whose patent expired in the United States on December 25, 2007. Prior to the appearance of that formulation on the shelf of my local pharmacy, my co-payment alone for the drug was $\$ 35$ for 30 tablets per month. The price to my health insurer was presumably a multiple of that figure. My price for the OTC formulation was \$19.99 for 120 tablets, i.e., a price reduction for me as co-payer of 86 percent. Because so many Indian drug exports are made at prices much lower than those at which patented and branded drugs are supplied in the United States, it would not be unreasonable to suggest that the quantity impact of Indian products is several times the $\$ 799$ million dollar value implied by the data underlying Figure 1. Indeed, the World Health Organization reports that "India ... accounts for about $1 \%$ of the world's production by value, but $8 \%$ by weight."8

Forced under the Uruguay Round Treaty to begin issuing already backlogged pharmaceutical product patents in March of 2005, Indian suppliers will lose their first-mover advantage in new generic drug markets and will have to compete with others who waited until U.S. or European patents expired. Some Indian firms have undertaken efforts to discover and develop their own new drugs for the world market. ${ }^{9}$ A leader among them is Ranbaxy, which in 2007 expended 6.4 percent of its sales dollars on research and development. ${ }^{10}$ By then Ranbaxy had several of its own new drugs in various stages of testing and had entered into several joint R\&D arrangements with multinational drug companies. Similarly, Dr. Reddy's Laboratories reported in its 2007 annual report an R\&D/sales ratio of 6.0 percent after netting out contributions from joint venture partners and four new drug molecules, all developed in cooperation with other companies, in clinical or pre-clinical testing. ${ }^{11}$

8 . The World Medicines Situation: 2004, p. 4.

9 . See Jean O. Lanjouw, "The Introduction of Pharmaceutical Patents in India," National Bureau of Economic Research working paper 6366 (1997).

10 . http://www.ranbaxy.com/investorinformation/news.aspx (February 4, 2008).

11 . http://www.drreddys.com/innovations/nces_pipeline.htm (March 24, 2008). 
My own experience suggests that Ranbaxy has powerful research and manufacturing capabilities. During the 1990s the Eli Lilly Company sought a second source for its antibiotic Ceclor (cefaclor), whose manufacture entails a particularly intricate ten-stage process. Ranbaxy was one of the half dozen finalists chosen from companies all around the world. Thus, India's ethical drug producers are already a significant influence in world markets (ignoring the ayurvedic products analyzed by Dr. Bode) and bid fair, despite the loss of generic sales advantages, continue to make inroads in the future.

\section{Japan}

Japan, ranked only 12th in Figure 1, with 2006 imports to the United States of $\$ 2.05$ billion, was also surprising, although less so than only from what I learned through the conference papers. My Table 1 data agree with Dr. Tomita's statement that Japan, with a high level of industrial development and a population of 128 million, is the world's second largest pharmaceutical market. My surprise was less than what it might have been because I had followed the pioneering research by L.G. Thomas, mentioned in none of the conference papers. ${ }^{12}$ Thomas found that, among nine major pharmaceuticalproducing nations in 1985, Japan had the second largest share of sales summed across the companies at home in those nine nations. See Figure 2. To be sure, Japan had a considerably larger population than any of the other nations in the sample other than the United States. Domestic demand alone might be sufficient to account for the indicated differences. But Thomas then went on to compute the percentage of national firms' 1985 sales achieved in nations among the nine but outside their home markets. The results are arrayed in Figure 3. Switzerland, Sweden, and the Netherlands, with small home markets but proficient pharmaceutical firms, do well. So do England and Germany, with similarly strong home-based firms and home markets of middling size. The United States also fares well, especially when one takes into account the enormous size of its home market. But France and Italy are under-achievers, and Japan shows up particularly poorly as an export generator.

12 . L.G. Thomas, "Industrial Policy and International Competitiveness in the Pharmaceutical Industry," in Robert B. Helms, ed., Competitive Strategies in the Pharmaceutical Industry (AEI Press: 1996), pp. 107-129. See also Thomas' book, The Japanese Pharmaceutical Industry: The New Drug Lag and the Failure of Industrial Policy (Edward Elgar: 2001). 
Thomas adduces several explanations for the differences in national industries' export performance. The most important new insight in his study, from the perspective of an American who had heard repeated complaints about the testing burdens and costs imposed upon pharmaceutical companies by the 1962 Kefauver-Harris Act reforms, was that the changes forced U.S. companies to focus their efforts on highly promising molecules and to minimize work on "me-too" drugs of low incremental therapeutic potential. During the 1950s, from 40 to 70 "new" drugs were being introduced into the U.S. market per year; after Kefauver-Harris strengthened standards of proof for efficacy and safety and increased clinical testing costs, the average introduction rate dropped below 20 per year. ${ }^{13}$ But the post-1952 drugs approved were those that had shown exceptional promise before the testing process was completed, and having overcome such high hurdles, they then succeeded also on world markets. Italy and France, on the other hand, had very low product approval thresholds at the time (since superseded by those nations' inclusion under the European Agency for the Evaluation of Medicinal Products (now called the European Medicines Agency). Thomas characterized French policies as "the French impressionist School" of drug safety regulation. The changes since 1985 undoubtedly underlie France's stronger performance evident in Figure 1.

Thomas explains Japan's particularly weak performance in 1985 as the result of several conditions. For one, he includes Japan among the nations with low standards for new drug product approval -- a judgment I have not seen evidence to overturn on the basis of the conference papers. Second, he observes (p. 111) that Japan's producers fragmented their innovative effort to focus on "minor local products," while only 10 percent of their innovations were characterized as "global products." ${ }^{14}$ This explanation is consistent with the conference analyses showing that Japanese pharmaceutical producers were induced to stress minor "me too" innovations by the tendency of price regulators to allow higher retail prices on drugs that could claim any

13 . See F. M. Scherer, Industry Structure, Strategy, and Public Policy (HarperCollins: 1996), p. 351.

14 . See also F. M. Scherer, The Economic Effects of Compulsory Patent Licensing (New York University 1977), p. 38, which shows that between 1940 and 1975, Japanese firms originated only 1.1 percent of the new drugs listed in Paul de Haen's worldwide compilation. The leaders were the United States with 69.1 percent, Switzerland with 7.6 percent, and the United Kingdom with 5.7 percent. 
innovative component at all and by the parallel tendency of prescribing physicians to favor products with the highest retail profit margins. To this I would add a third more speculative observation. My observation suggests that Japan is home to some of the world's most capable biotechnical companies, who among other things collaborated in the creation of synthetic erythropoietin and the enzymes needed to produce high-fructose corn syrup. I have reason to believe that main-line Japanese pharmaceutical firms also have strong technological skills. I believe it could be shown that many pharmaceutical products invented by Japanese companies have been licensed for sale in the United States and Europe by multinationals at home outside Japan. My speculative hypothesis is that Japanese firms find the challenges of surmounting Food and Drug Administration approval hurdles and establishing extensive sales networks in the United States sufficiently formidable that they have emphasized licensing rather than direct sale. It is far from clear why this should be so; European firms have not been intimidated by the entry barriers. Unfortunately, none of the conference papers illuminates this important aspect of the Japanese industrial performance.

\section{Physician Dispensing More Generally}

If there is an overriding theme in the conference papers, it is the dominant role physicians play in dispensing the medicines they prescribe, rather than allowing specialization of functions, with physicians making prescription decisions and pharmacists dispensing the desired products. This theme is addressed in the papers by Li \& Reimers, Kwon, Iizuka, Tomita, Sun \& Meng, Huang \& Yang, Hsieh and Eggleston. Physician-oriented dispensing has predominated in nations with long traditions of ayurvedic medicine dispensing by practitioners with at best informal medical training and appears to have been carried on as modern science-based pharmaceuticals entered the health care picture. China, Korea, Japan, and Taiwan appear to have been the prime loci of physician prescribing, although from the Bode paper, one might infer that it is found also in India.

Dispensing of pharmaceuticals by physicians has thrived in part through tradition, but also, and probably more importantly, because it is profitable. Influenced perhaps by traditional norms, public health care reimbursement authorities have tended to allow only low fees for diagnostic activity by physicians, assuming tacitly or explicitly that physicians will earn their bread with the profit margins on drugs they dispense. 
Karen Eggleston and others suggest some possible advantages from the approach. Miscommunication may be avoided -- a benefit that must be appreciated by any American who has received an illegible prescription from his or her physician, but that is now vanishing as computers generate readable prescriptions and transmit them electronically to pharmacies. See also the Liaw paper. There may be economies of scope in combining prescription and dispensing at one locale, although countervailing economies of specialization seem equally plausible. And the placebo effect known to exist even with the most high-powered science-based pharmaceuticals may be stronger when the prescribing physician pops the pill or squeezes the syringe. On the other hand, there are compelling disbenefits. Assuming that physicians will glean a significant part of their income through prescriptions, government price controllers and price-setting drug manufacturers allow generous margins between wholesale and retail prices, which in turn encourage physicians to over-prescribe medications quite generally and in particular to substitute high-priced, high-margin innovative drugs for older but equally effective entities. For antibiotics, which, some of the conference papers suggest, are prescribed much more frequently with physician dispensation than under separation of functions, the tendency toward excessive usage and harmful externalities may be particularly egregious. An antibiotic dispensed unnecessarily to one patient can lead to bacterial resistance, and the recipient may transmit the resistant bacteria to other individuals, requiring ever more high-powered antibiotics in a kind of arms race.

Some of the papers suggest that the use of generic drugs is encouraged by the integration of diagnosis with dispensation because absolute margins on generics tend to be higher, yielding the dispensing physician a higher margin. Doubts intrude on this, considering the relatively low generic usage rates achieved in Asian nations relative to the above 50 percent average now prevalent in the United States and parts of Europe. ${ }^{15}$ The logic in favor of a generic bias follows the empirical findings of prior studies, notably in the United States, showing higher average profit margins on generics. However, I

15 . Professor Iizuka describes how, beginning in 2002, the Japanese government tried to encourage generic prescribing by altering the parameters of prescription pads. How such changes affected the acceptance of generics in the United States is analyzed thoroughly in Allison Masson and Robert L. Steiner, Generic Drug Substitution and Prescription Drug Prices, U.S. Federal Trade Commission staff report, 1985. The transmission of economic knowledge appears to occur less completely than the transmission of biological knowledge! 
am unsure that relationship carries over into a world in which generics are dispensed more frequently than branded drugs. There are countervailing arguments. On the one hand, those who establish and/or reimburse prices may wish to set them in such a way as to encourage generic usage. It is not clear why branded drug manufacturers should desire this, nor is it obvious for drug retailers. The case for higher margins at the retail decision-making level follows a broader logic prevailing for private-label goods more generally: they turn over less rapidly on the retailer's shelf, and therefore higher margins are required to induce their stocking. ${ }^{16}$ But if generics are an incomplete subset of all pharmaceutical entities and if in the aggregate more generic pills are dispensed than branded drugs, the turnover rate for the drugs on which generics exist should be higher, not lower. Thus, the rationale for higher margins fades. This, it seems to me, is a fruitful area for careful new research both in Asia and the United States.

Another important point on generics needs to be emphasized. The best empirical studies on generic pricing in a more or less free market support Augustin Cournot's prediction that prices are lower, the larger is the number of competing sellers. Richard Caves and associates found, for example, that with one generic producer, the generic product's price average 68 percent of the pre-entry branded product's price. The average generic price dropped to 50 percent with three generic rivals, 29 percent with 10 generics, and 17 percent with 20 generics. ${ }^{17}$ This phenomenon could explain the evidence in conference papers and also for Europe that generic product prices tend to be higher relative to their branded counterparts than is common in the United States. The United States is a huge market, and so, given the typically modest fixed costs required to enter generic production, there is often room in the market for numerous suppliers, which in turn leads to low prices. Many Asian national markets on the other hand are much smaller, and in China, they may be fragmented inter alia by provincial organization and other barriers to internal trade. Therefore, it may be more difficult to realize fully the benefits of

16 . National Commission on Food Marketing, Technical Study No. 10, Private Label Products in Food Retailing (Washington: USGPO, June 1966), pp. 65-77.

17 . R. E. Caves, Michael Whinston, and Mark Hurwitz, "Patent Expiration, Entry, and Competition in the U.S. Pharmaceutical Industry," Brookings Papers on Economic Activity, Microeconomics: 1991, pp. 1-48. See also Henry Grabowski and John Vernon, "Brand Loyalty, Entry, and Price Competition in Pharmaceuticals after the 1984 Drug Act," Journal of Law \& Economics, vol. 35 (October 1992), pp. 331-350. 
generic competition. An escape hatch could be to import generics from specialist firms in e.g. India and Brazil. But if national or provincial health authorities express preferences in favor of domestically supplied products, the dilemma of small market size persists. Here too, a much more comprehensive analysis is warranted.

Recognizing the disadvantages on balance of integrating diagnosis with drug dispensing, the nations on which the conference authors focus have taken a variety of measures to encourage separation or disintegration. The papers make it clear that progress has been made, but the transition has not been easy. Resistance appears to have been fiercest in Korea, but it was evident elsewhere too. Physicians have defended their traditional turf by emphasizing injectables, more difficult to administer outside the office, over pills; and they have entered profit-sharing arrangements with nearby seemingly independent pharmacists and steered their patients toward them. Dr. Kwon's suggestion that governments raise the pay of generic-prescribing physicians suggests a degree of micro-management that might horrify more market-oriented Americans. Even more surprising is his report that when generic competition begins, government pricing authorities set the first generic entrant's price at 85 percent of the (reduced) branded drug price and that entrants 2 through 5 receive 85 percent of the first generic entrant's price.

\section{Price Controls}

These last two examples are merely the tip of an iceberg. In all the nations on which the papers have focused, it is customary for pharmaceutical prices to be regulated and/or fixed by government health care authorities. A surprise to me is that none of the papers mentions an authoritative work on the use and effects of government price controls in the pharmaceuticals industry: Patricia Danzon's book, Pharmaceutical Price Regulation. ${ }^{18}$ Most of the well-known techniques are in evidence in the conference papers: reference pricing against the prices charged in other nations, reference pricing against drugs in the same therapeutic category, arbitrary across-the-board percentage reductions within broad classes of drugs, cost-based percentage markups, variations in allowed margins to encourage drug innovations (which, the papers show, more often encourages minor me-too variants, changes in the strength of active ingredients, or even name changes), flat aggregate budgets 
for drugs, and much else. The principal lacunae are the uniquely British system of setting company-wide reimbursements to allow appropriate rates of return on investment, including $R \& D$ investment; ${ }^{19}$ and targeting for percentage price reductions mainly the drugs with the largest profit margins - a proposal on which presidential wife and now presidential candidate Hillary Clinton came to grief in the early 1990s. Combined with physician-based dispensing, as I have observed previously, some of the methods used by Asian price controllers are so distortionary that, by encouraging over-prescribing or inappropriate substitutions, they increase rather than reduce overall health care expenditures.

Somewhat outside the realm of price controls, but equally controversial in U.S. political circles, is vigorous negotiation over prices by government health authorities with would-be pharmaceutical suppliers. Professor Lofgren provides an account of the Australian system, which, according to Professor Kwon, has also been adopted in Korea and proposed for Taiwan and (Messrs. Sun \& Meng report) for China. Similar negotiations are carried out by individual health maintenance organizations in the United States, although the success of their efforts has been curbed by federal legislation requiring any discounts they receive to be matched in the prices reimbursed by governmental authorities on pharmaceuticals dispensed under the Medicaid program.

What is left unclear in the conference papers is the hardest part: how a decision-maker, governmental or private, determines how much of a price premium is warranted by unique advantages a particular drug might offer. Australia appears to have made the most progress in this direction. Detailed case studies could enhance our understanding of how decision-makers cope.

\section{Distribution Channels and Margin Policy in China}

An important component of price controls is the determination of what margins will be allowed at each stage in the channels of distribution from manufacturer to patient. Here I was astonished more than by anything else I read in the conference papers.

19 . For a difficulty with the system, see F. M. Scherer, "US Industrial Policy and the Pharmaceutical Industry," in Adrian Towse, ed., Industrial Policy and the Pharmaceutical Industry (London: Office of Health Economics, 1995), pp. 26-39. 
The papers by Huang \& Yang and by Li \& Reimers provide fairly consistent estimates of the share of retail drug prices obtained by various stages in the chain of distribution, i.e., manufacturers, wholesalers, and retailers ( the last including hospital pharmacies and physicians). Their general estimates are in ranges, which I have converted (in parentheses) so that the median stage shares sum to 100:

$\begin{array}{lcc} & \text { Huang \& Yang } & \text { Li \& Reimers } \\ \text { Manufacturers } & 10-50(32.7) & 10-50(32.7) \\ \text { Wholesalers } & 3-20(12.6) & 3-10(7.6) \\ \text { Retail } & 30-70(54.6) & 30-80(59.8)\end{array}$

Huang \& Yang also provide a single example, for omeprazole (generic Prilosec):

$\begin{array}{ll}\text { Manufacturer } & 14 \% \\ \text { Wholesale } & 20 \% \\ \text { Retail } & 66 \%\end{array}$

The surprisingly high retail margins are said to cover physicians' dispensing fees, the profit margins of hospitals, brokerage paid to hospital administrators, and bidding expenses.

The accounts were surprising to me because I had worked with similar distribution channel breakdowns for the U.S. pharmaceutical system. During the mid-1970s, the average value chain share for retailers was 40 percent, for wholesalers 9 percent, and for manufacturers 51 percent. ${ }^{20}$ By the late 1990s, several important changes had been wrought. At the retail level, resale price maintenance arrangements were outlawed, forcing retailers to compete for business on the basis inter alia of their margins. Pressure was also brought to bear on them by insurance companies and health maintenance organizations and by the government's Medicaid administrators, reducing the average retail

20 . F. M. Scherer, "How US Antitrust Can Go Astray: The Brand Name Prescription Drug Litigation," International Journal of the Economics of Business, vol. 4 (1997), p. 245. 
margin to 20 percent of the ultimate sales value. ${ }^{21}$ Numerous efficiencyincreasing measures reduced the average wholesaler margin to 4 percent, leaving 76 percent for manufacturers.

Figure 4 brings together these various channel share estimates. Clearly, in part because of physician dispensing and in part because Chinese health care authorities use retail margins to pay physicians for their services, manufacturers in China receive a much smaller share of the pharmaceutical value chain than their counterparts in the United States. This evidence has two somewhat different but probably complementary explanations: the distribution system in China is quite inefficient, and it leaves for manufacturers a relatively small share of ultimate pharmaceutical sales realizations to reimburse such activities as research and development, testing, and quality control.

Professors Li \& Reimers report that, after a visit by a Chinese official to the United States, an electronic system for procuring drugs was implemented in diverse Chinese provinces beginning in the early 2000s. However, the use of electronics in China as compared to the United States seems to be quite different. In Beijing, the system is apparently used to elicit price bids from manufacturers which are then reviewed by expert committees and either accepted, rejected, or subjected to renegotiation. The bid data are apparently then transmitted to using (i.e., retail) agencies. In the United States, prices tend to be negotiated face-to-face between payers -- hospitals, health maintenance organizations, and pharmacy benefit management companies -and the manufacturers. The bids are then entered confidentially into the computers of wholesalers, who take the merchandise from manufacturers, deliver it to dispensers at the negotiated prices, and then obtain a monetary "grantback" from the manufacturer to the wholesaler to reimburse the wholesaler for any discounts it gave to ultimate customers. Retailers on the other hand were usually served, at least during the 1990s, at posted and relatively invariant prices. ${ }^{22}$ For China, electronics serves to support a bidding and tracking system; for the United States, an accounting and reimbursement system.

21 . "Profile of the Prescription Drug Wholesaling Industry," http://www.fda.gov/oc/pdma/report2001/attachmenttg/3.html (downloaded February 25, 2008).

22 . See again Scherer, supra note 16. 
I cannot pretend to understand fully the Chinese bidding system, which appears to generate a remarkably broad distribution of prices for products that must in many instances be similar. It seems also to offer transparency of successful bids to the various parties involved. But transparency is the antithesis of effective competition. ${ }^{23}$ The free-market buyer who elicits a substantial discount and makes it public will compel other sellers to offer similar discounts, and knowledge that this will happen deters sellers from offering substantial discounts in the first place. Clearly, an analysis of the Chinese electronic bidding system that recognizes this important truth is in order.

Professors Li \& Reimers report that China has 8,000 active drug distributors (which in the context presumably means wholesalers), including 120 in the Beijing area alone. Messrs. Sun \& Meng report the number of wholesalers as 12,000. This too is remarkable. Efficient wholesaling entails a tradeoff between proximity to end customers and hence rapid delivery, which implies regional decentralization in a nation as large as China, and concentration of supplies at relatively few nodes so as to achieve economies of scale aggregating inter alia random demand fluctuations. ${ }^{24}$ That tradeoff drives market structures toward concentration of wholesalers. In the United States, 90 percent of all sales are made by five full-line drug wholesalers ${ }^{25}$ and the total number of wholesale drug establishments is estimated (with some reporting imprecision) as 3,283, among which 110 establishments with annual sales exceeding $\$ 50$ million each accounted for 89 percent of total wholesale shipments. ${ }^{26}$ From this I suspect that China has struck the wrong tradeoff and needs to make its drug wholesaling channels more efficient by concentrating

23 . See F. M. Scherer, Industrial Market Structure and Economic Performance (RandMcNally: 1980), pp. 208-210, 248-249, and 449-453. See also the U.S. Supreme Court opinion in Brooke Group Ltd. v. Brown \& Williamson, 509 U.S. 209, 238 (1993), discussing tacit coordination of oligopolistic pricing and observing that "Uncertainty is an oligopoly's greatest enemy."

24 . For a review of the substantial operations research literature on this point, see F. M. Scherer, Alan Beckenstein, Erich Kaufer, and R. D. Murphy, The Economics of Multi-Plant Operation (Harvard University Press: 1975), pp.56-62.

25 . Supra note (fda report).

26 . U.S. Bureau of the Census, Census of Wholesale Trade: 1997, Subject Series, Table 4 (for industry category 4222101). 
individual units. Electronics cannot save the day unless it is accompanied by appropriate operations research analysis and structural rationalization. Doing so is a major challenge for China's future.

\section{Chinese Production Facilities}

Scale economy sacrifices are also implied by the large number of production facilities in the Chinese industry -- estimated by Messrs. Li \& Reimers and also by Liu and Zhang to be 5,000, 30 percent of whom are said to be running in the red. U.S. Census statistics do not permit an exact estimate of the number of manufacturers, since companies producing conventional pharmaceuticals, biologics, and other medicinals are reported in separate but possibly overlapping categories. A maximum estimate is that in 1997, the U.S. industry, presumably much larger than China's, included 1,286 companies, of whom the largest 20 originated 70 percent of total industry sales. ${ }^{27}$

There are economies of scale in manufacturing, and perhaps more importantly, economies of scale in quality control. ${ }^{28}$ Small plants are almost certain to have difficulty affording specialized quality control staff and carrying out the tests needed to ensure product safety. And it is hard to imagine how a regulatory agency paralleling the U.S. Food and Drug Administration could reliably monitor manufacturing practices in 5,000 plants. This problem is likely to underlie the much-publicized safety problems experienced recently by Chinese pharmaceutical (and pharmaceutical ingredient) producers, highlighted in the Santoro-Liu and Liu-Zhang papers. Without an unsullied reputation for consistently high product quality, Chinese pharmaceutical makers will have great difficulty selling their products in world markets. Given the complexity of the monitoring task, executing a corrupt head of China's drug regulatory agency is not likely to provide a sufficient remedy. ${ }^{29}$ Again, restructuring the industry to a more compact set of plants whose operations can be monitored consistently and thoroughly appears necessary.

27 . From U.S. Bureau of the Census, Concentration Ratios in Manufacturing: 1997, Table 3.

28 . See F. M. Scherer, "An Industrial Organization Perspective on the Influenza Vaccine Shortage," Managerial and Decision Economics, vol. 28 (2007), pp. 395-405.

29 . See "A Chinese Reformer Betrays His Cause, and Pays," New York Times, July 13, 2007, p. 1. 
The conference papers left unclear how this vital restructuring will be accomplished. Market processes would do so, weeding out the firms whose costs are too high or whose quality is too low. It seems doubful that markets will be given this much scope for structural reform in China. But if the job is to be done through central planning or (more likely) decentralized provincial planning, it is far from clear how planners will obtain the information needed to determine which firms' costs are too high relative to quality or which firms offer exceptionally high quality. Only the cases of egregious quality control failure appear susceptible to relatively easy structural decision-making.

\section{Innovation and Patents}

Pharmaceuticals is one of the world's most technologically dynamic industries. The links to basic science are tight; pharma companies in affluent economies have the highest company-financed research and development-tosales ratios of any industries for which data are published; and for nearly a century new products have flowed out to raise human health standards materially. ${ }^{30}$ One looks for recognition of these facts in the conference papers but, with the exception of the proposals by Henry Grabowski and John Barton, finds little emphasis on technological innovation. Will Asian companies continue (with a few exceptions, e.g. Japan and Singapore) continue to be technological followers or free-riders? Or will the future bring a great leap forward?

Private investment in pharmaceutical innovation is driven by the hope for substantial profit rewards. It is doubtful whether the price control regimes deployed in most of the nations surveyed by conference papers provide much incentive for R\&D investments. To be sure, some price control authorities adjust margins upward for newer, presumably more innovative, products. But the main effect appears to have been a stimulus for minor "me too" product variants and size or compounding changes. One fundamental challenge is that, studies by Henry Grabowski and others have shown, the distribution of profit returns to new drug products successful enough to secure regulatory agency approval is highly skew. ${ }^{31}$ The top ten percent of new pharmaceutical

30 . See e.g. my survey, "Pharmaceutical Innovation," forthcoming in Bronwyn Hall and Nathan Rosenberg, Handbook on the Economics of Technical Change.

31 . See e.g. Henry Grabowski, John M. Vernon, and Joseph DiMasi, "Returns on Research 
products in terms of profit returns garner roughly half of all new products' profits. Many marketed new products fail to cover the capitalized costs of their development and testing, including the costs of failed R\&D efforts. In short, new product development is highly risky. In an entrepreneurial culture, and especially in newly-emerging fields such as biotechnology, the skewness of rewards may actually encourage innovative risk-taking. ${ }^{32}$ But it is rare for price controllers to allow the kinds of profit margins Joseph A. Schumpeter had in mind describing his model of capitalist dynamics: ${ }^{33}$

Spectacular prizes much greater than would have been necessary to call forth the particular effort are thrown to a small minority of winners, thus propelling much more efficaciously than a more equal and more 'just' distribution would, the activity of that large majority of businessmen who receive in return very modest compensation or nothing or less than nothing, and yet do their utmost because they have the big prizes before their eyes and overrate their chances of doing equally well.

If price controls are to be the norm, there remain two main alternatives for attaining an innovative Asian pharmaceutical industry. For one, investments in innovation may be driven, as they are in some European countries, by the hope of a successful product launch in the (thus far) largely unregulated U.S. market. If so, Asian companies will have to develop their pharmaceutical export capabilities -- something which, we have seen, has often eluded technologically progressive Japanese producers, but not (with a strategy emphasizing low generic prices rather than innovation) the Indian industry. Or alternatively, it may be possible to achieve a mix of government R\&D subsidies, academic research, and private sector production and marketing skills that sustains innovative performance. To do so is likely to be difficult, but not, as the experience of the U.S. weapon systems industry shows, impossible. Success would require solving two difficult problems. First, at the drug discovery stage, the uncertainties are formidable, so it is

and Development for 1990s New Drug Introductions," PharmacoEconomics, vol. 20 Supplement 3 (2002), pp. 16-27.

32 . See my paper, "The Innovation Lottery," in Rochelle Dreyfuss et al., eds., Expanding the Boundaries of Intellectual Property (Oxford University Press: 2001), pp. 3-21.

33 . Capitalism, Socialism, and Democracy (Harper: 1942), pp. 73-74. 
necessary to ensure that many alternatives are explored -- i.e., to follow Mao's maxim, "Let one hundred flowers bloom." But second, costs soar when clinical testing begins, and so there must be a decision-making process with strong scientific competence, freedom from political biases, and the willingness to take big calculated risks. One would like to know more about the strategies Asian science policy-makers and companies in fact contemplate, if indeed they do so.

Except for Professor Barton's paper, the conference offerings are also largely silent on what I consider to have been one of the great policy debates in recent years -- whether nations that have long chosen not to award pharmaceutical product patents should be required under the Uruguay Round agreements to begin conferring them. The Treaty of Marrakech is a reality; India began issuing drug product patents in March 2005; conference subject nations such as Thailand and South Korea (earlier, in response to U.S. pressure) have joined the patent-granting parade; and all least-developed nations will be required to comply by the year 2016. What changes will their pharmaceutical industries have to make? How will the availability of low-cost medicines to the least affluent nations be affected? What incentives can be created, as Grabowski and Barton ask, for the discovery and development of new medicines combatting diseases prevalent mainly in parts of the world with too little purchasing power to offer much hope of high profits contingent upon technological success?

Related to these questions is a question about the use of a potentially important escape clause allowed by the Marrakech Treaty -- compulsory patent licensing. Canada, the United States, Brazil, South Africa, and others have used the threat of compulsory licensing to win much lower prices for drugs combatting AIDS and other lethal diseases. Thailand has been a leader in actually issuing compulsory licenses -- e.g., for the production of several important drugs, including the life-saving but egregiously priced protease inhibitor Kaletra. I was shocked to read in Dr. Ratanawijitrasin's paper that the United States government put Thailand on its priority watch list in May 2007 for its compulsory licensing of drug patents. A similar patent-linked action by the United States in 1991 led to proposed legislation in the Thai parliament precipitating a no-confidence vote and dissolution of the government. Will we Americans ever learn to let other governments make their own decisions freely within the latitude allowed by international law? 
I was also surprised to learn from Dr. Ratanawijitrasin that Thailand is producing generic erythropoietin (EPO). My surprise had nothing to do with compulsory licensing; Amgen's basic U.S. epoetin alpha patent expired in 2004 (although other patents continue to be disputed). But biologically engineered drugs are said to be much more difficult to produce than so-called smallmolecule drugs, which are the only drugs on which a fast-track generic approval protocol was created under the U.S. Hatch-Waxman Act of 1984. In 2006 the European Medicines Agency issued guidelines for the approval of "biosimilar" generics and granted two authorizations for the production of generic human growth hormones. During the past year the U.S. Congress has been considering legislation to allow biological generic approvals, but was deadlocked on the issue and referred it recently to the Food and Drug Administration for consultation. My surprise from the Thai evidence led to further investigation, revealing that the original alpha and other forms of EPO are in fact produced in many nations, including India, China, Japan, HongKong, Korea, and Vietnam as well as Thailand. ${ }^{34}$ A detailed case study of various nations' experience in producing generic EPO could make a significant contribution to the U.S. policy deliberations.

\section{Conclusion}

To sum up, the papers presented at this conference offer fascinating insights on how an important industry is emerging in Asia and how public policies have been structured to encourage it in some ways and hold it back in others. I have identified questions on which I should like to know much more. But I can also report that I have learned a lot from the conference papers.

34 . "Erythropoetin," in the German language, Wikipedia, especially the section on

"Nachahmerprepaerate" (imitator preparations), accessed March 24, 2008. 
Table 1

Estimated National Pharmaceutical Production Value: 1997*

Millions of Dollars

United States

97,505

Japan

56,768

United Kingdom

23,326

Germany

23,088

France

22,518

Switzerland

$20,000^{\mathrm{a}}$

Spain

16,038

India

6,012

Canada

5,561

Italy

4,938

South Korea

4,815

Denmark

4,596

Sweden

4,391

Netherlands

3,536

Singapore

3,012

Mexico

2,973

Belgium

2,656

Portugal

2,460

Austria

2,352

Australia

2,261

$\underline{\text { Other Asian Pacific }}$

Indonesia

1,314

Philippines

1,147

Thailand

$741^{\mathrm{b}}$

Pakistan

711

Bangladesh

320

China

214

Malaysia

178

Myanmar

129

New Zealand

Sri Lanka

$95^{\mathrm{c}}$

$9^{\mathrm{b}}$ 
*Source: World Health Organization, The World Medicines Situation (2004), Appendix Table 1.
${ }^{\text {a }}$ Estimated from report text.
${ }^{\mathrm{b}}$ Value for 1991.
${ }^{\mathrm{c}}$ Value for 1985. 


\section{Figure 1}

Leadding Pharmaceutical Importers into the United States, 2006

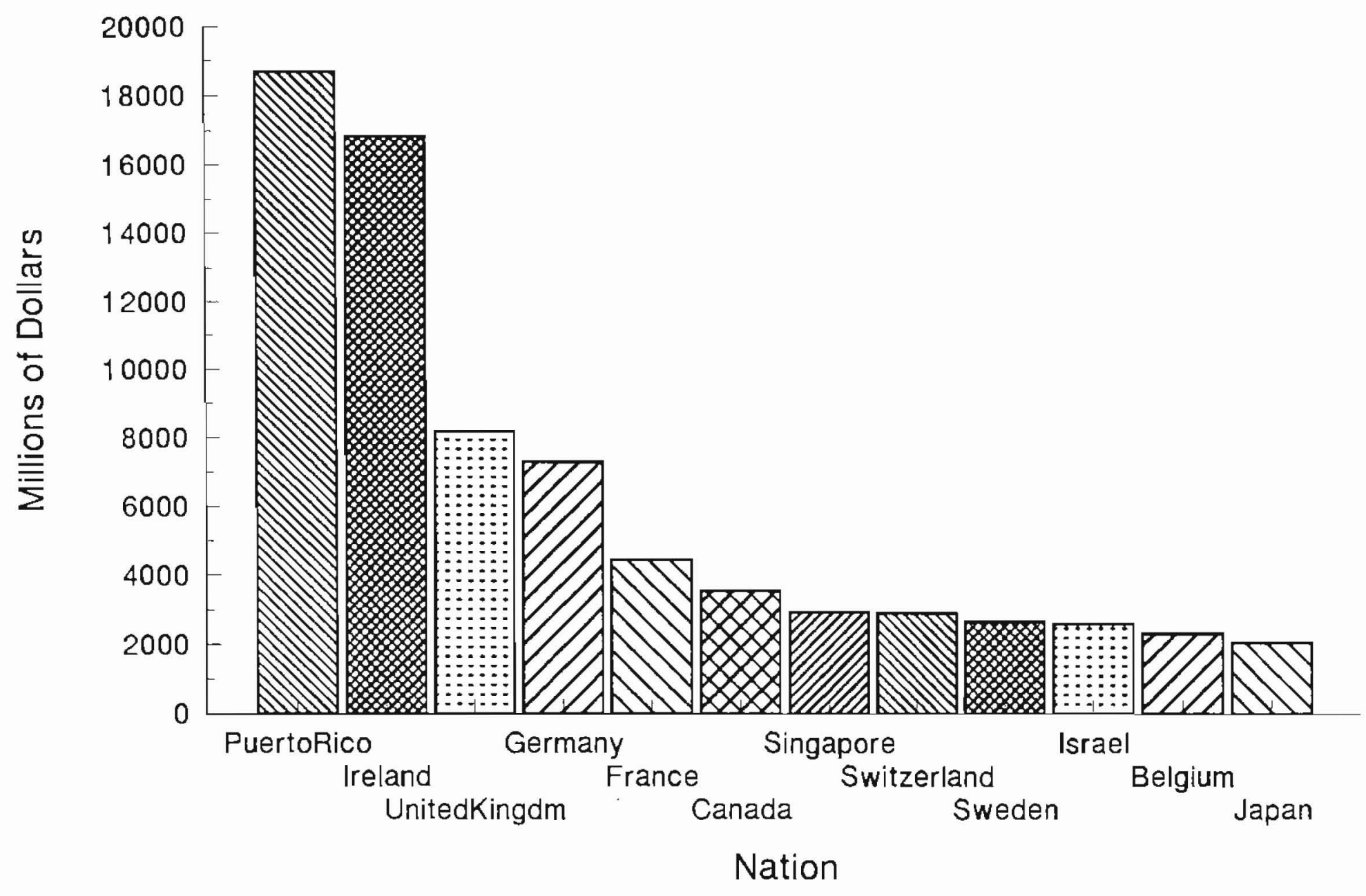


Figure 2

National Companies' Shares of Nine-Nation Market

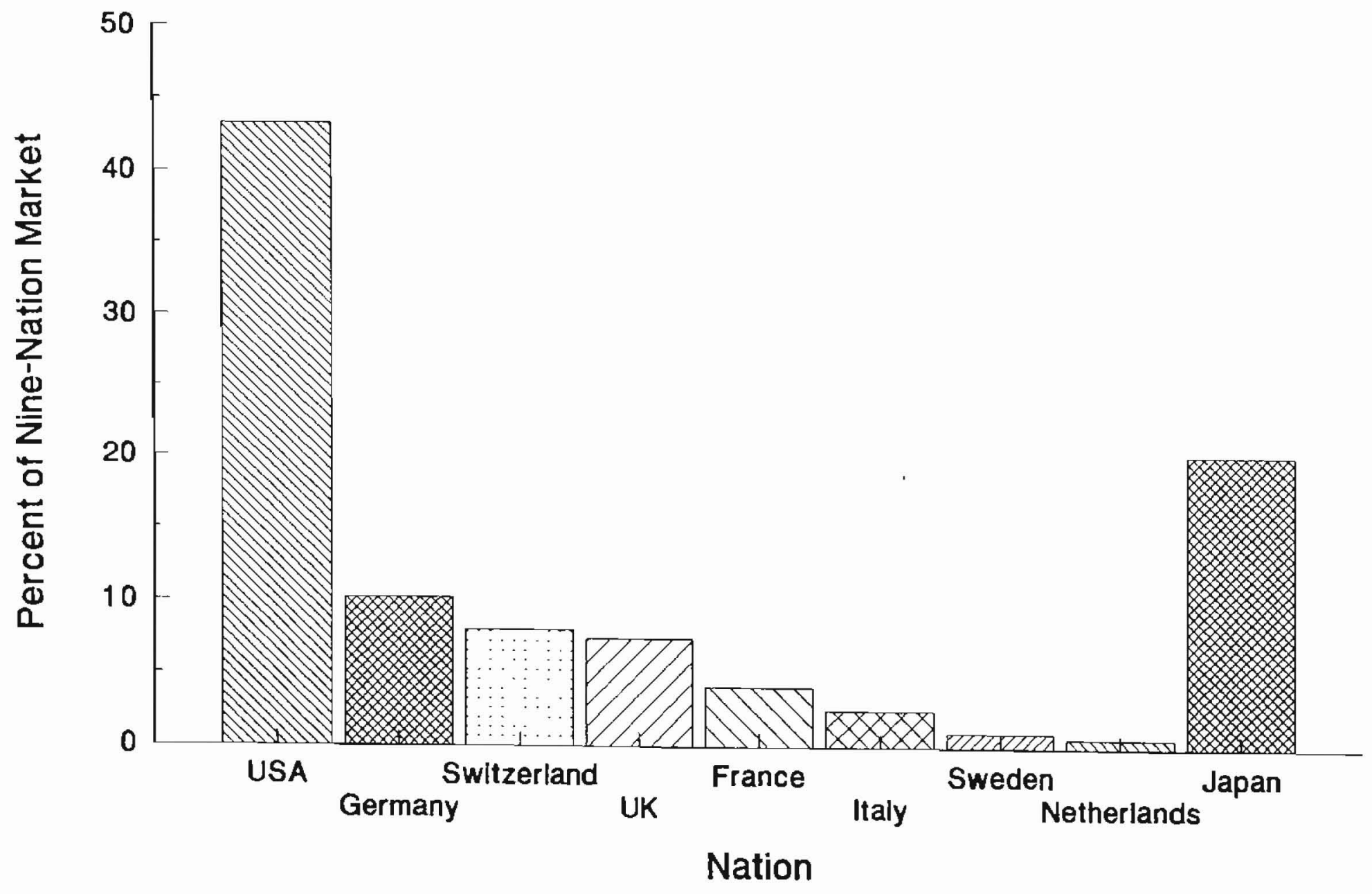


Figure 3

Percent of Multinational Drug Company Sales Outside Home Market Source: Thomas (1996)

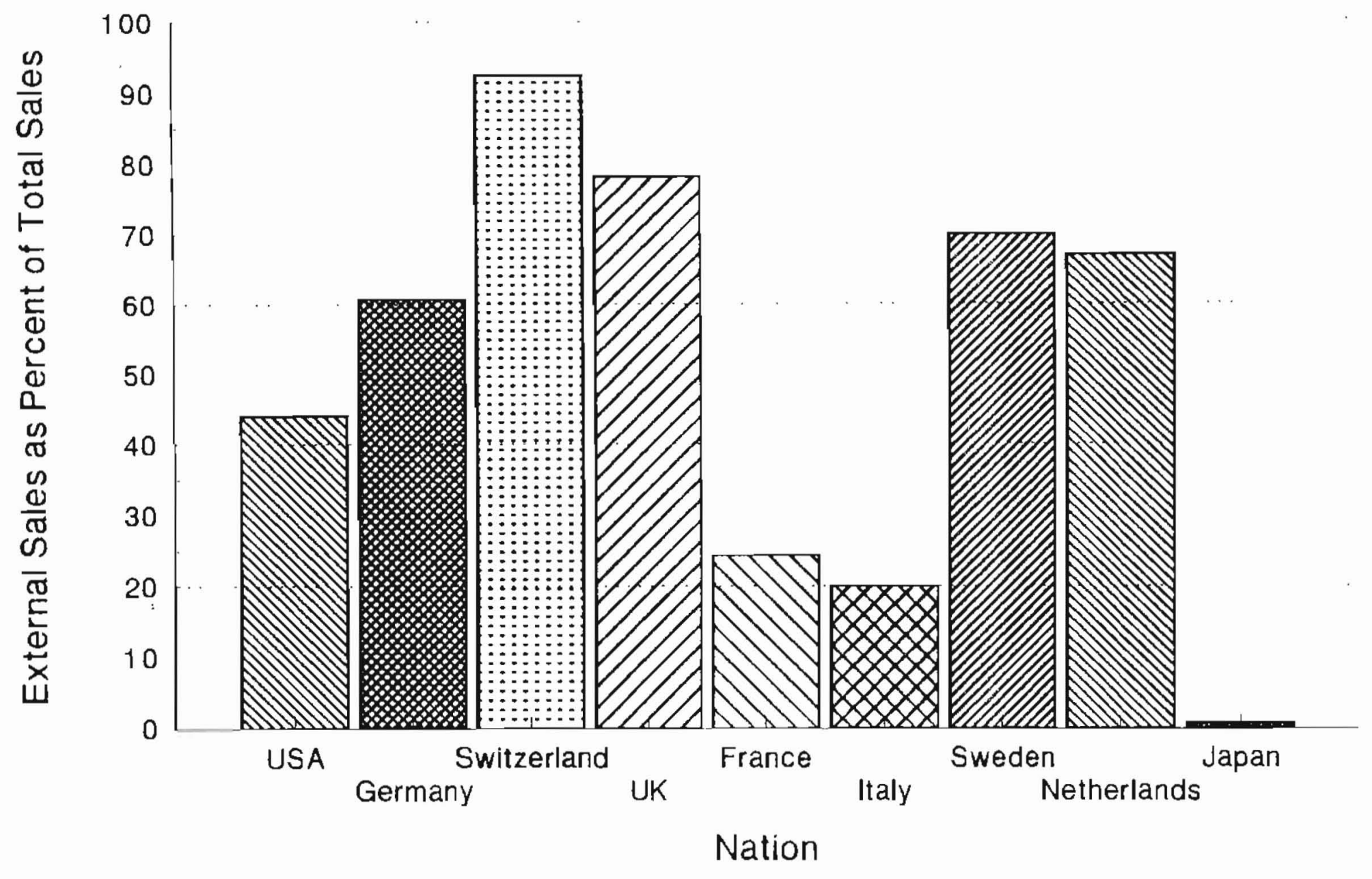


Figure 4

\section{Percent Distribution of Value Chain Elements}

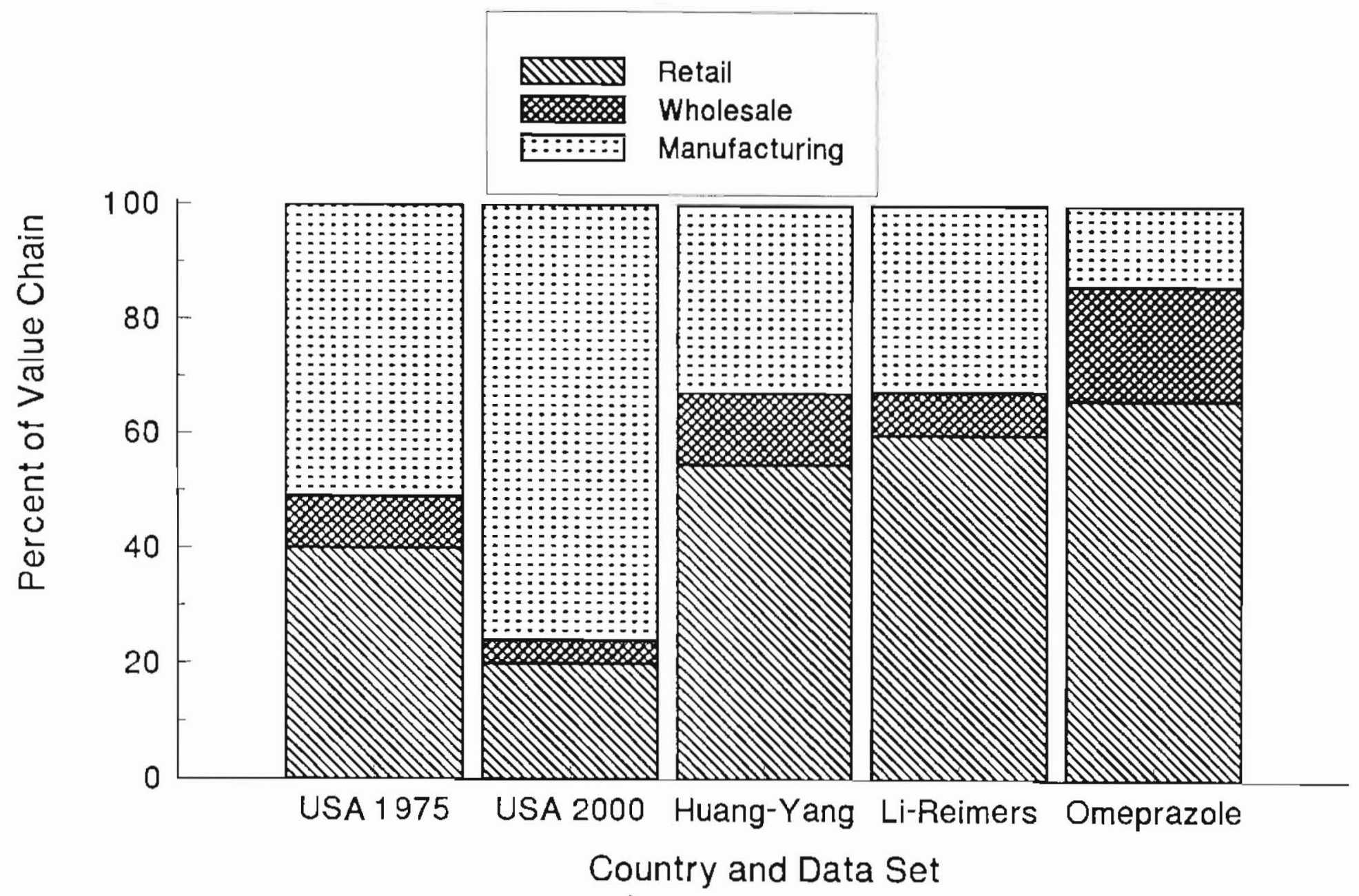

